\title{
MÁSKÉPP - AZ EGYÉNI SZÜKSÉGLETEKHEZ, IGÉNYEKHEZ IGAZÍTOTT PEDAGÓGUS-TOVÁBBKÉPZÉS A GYAKORLATBAN
}

\section{MARTON ESZTER* - PAPP GABRIElla ${ }^{* *}$ - PERLUSZ ANDREA}

\author{
* az ELTE Bárczi Gusztáv Gyógypedagógiai Kar \\ tanársegédje \\ eszter.marton@barczi.elte.hu \\ **az ELTE Bárczi Gusztáv Gyógypedagógiai Kar \\ föiskolai tanára \\ gabriella.papp@barczi.elte.hu \\ *** az ELTE Bárczi Gusztáv Gyógypedagógiai Kar \\ tanszékvezető főiskolai tanára \\ perlusz@barczi.elte.hu
}

\begin{abstract}
„A tankötelezettség kiterjesztéséböl és az integrációból adódó feladatok” címet viselo" alprojekt, mely a TÁMOP-4.1.2-08/2/B/KMR-2009-0001 számú, „Pedagógusképzési hálózat Közép-Magyarországon” elnevezésü pályázati programban valósult meg, kidolgozott egy középiskolai együttnevelést segitö tréningalapú továbbképzési programot. A tanulmány bemutatja a középiskolás korú sajátos nevelési igényü tanulók helyzetét Magyarországon, valamint a továbbképzés alapjául szolgáló igényfelmérés eredményét, a képzés felépitését, és a pedagógusok képzést követö elégedettségének mértékét.
\end{abstract}

A pedagógusképzés és -továbbképzés az Európai Unióban az elmúlt évtizedben erőteljes figyelmet kapott. Ennek oka többek között az a felismerés volt, hogy a megváltozott tanulási, osztálytermi környezetben a tanítás-tanulás folyamatának hatékonyabbá tétele nem képzelhető el korszerű elméleti, gyakorlati tudással és elkötelezettséggel rendelkező pedagógusok nélkül. A témával foglalkozó szakemberek egyrészt górcső alá vették az egyes államok gyakorlatát, másrészt elvárásokat fogalmaztak meg a tagállamok számára és a tudásalapú társadalom megteremtése érdekében ajánlások születtek a pedagógusképzés korszerüsítésére (Szegedi, 2010; Falus, 2010; Stéger, 2010).

Az európai trendekkel összhangban, a fenti kiemelt szempontokra figyelemmel született meg az általunk kidolgozott program, céljait tekintve újszerü pedagógus továbbképzési forma és tartalom. A kutatás és fejlesztés hátterét a TÁMOP-4.1.208/2/B/KMR-2009-0001 számú pályázat képezte, amely az Eötvös Loránd Tudományegyetem Pedagógiai és Pszichológiai Kara által elnyert a „Pedagógusképzési hálózat Közép-Magyarországon” elnevezésű projekt volt, Hunyady György vezeté- 
sével. A projekt egyik alprojektje „A tankötelezettség kiterjesztéséből és az integrációból adódó feladatok" címet viselte, vezetője Papp Gabriella volt, futamideje 2009-2011-ig tartott. ${ }^{1}$ Az alprojekt céljai között egy tanulmánykötet megjelentetése (Papp, 2011), és egy, a középiskolai együttnevelésre vonatkozó protokoll kidolgozása mellett kiemelt szerepet kapott egy tréningalapú továbbképzési terv kidolgozása, és kipróbálása is, olyan középiskolában dolgozó pedagógusok számára, akik sajátos nevelési igényü vagy beilleszkedési, tanulási, magatartási zavarral küzdő tanulókkal foglalkoznak. Kiemelt célként jelent meg a projekt eredményeinek beépítése a BA és MA szintü gyógypedagógus képzés rendszerébe.

A kutató csoport létrehozását a kutatási terv elkészítése, majd a kutatási probléma azonosítása követte. A szakirodalom feldolgozása nem csak a kutatott tartalomra terjedt ki, hanem a pedagógus továbbképzés korszerü elemeinek a feltárását is megcélozta. Ez utóbbinál kiemelten fókuszáltunk azokra a jellemzőkre, amelyek az iskola innovációs tevékenységét hangsúlyozzák. Korábbi tapasztalataink alapján egyetértett a csoport abban, hogy megfelelö ösztönző környezet mellett az intézmények, az iskolák maguk is teremtik az új és korszerủ pedagógiai attitűdöt, képességet, tudást, azonban mindez csak akkor tud tovább terebélyesedni, ha a kívülről kapott segítség igazodik e folyamathoz, s együttmúködést kínál a további építkezéshez.

A fentiek miatt a továbbképzés tervezésekor különös figyelmet szenteltünk annak, hogy a résztvevők a későbbiekben tudásmegosztóként is szerepet kapjanak, képesek legyenek a megszerzett tudást hálózatba kapcsolódva továbbadni. Az egymástól tanulás lehetősége, az innovációban való részvétel az iskola kultúrájának alakulására is hatással van. A tanulóközösséggé válás hosszú folyamatában a képzőknek mindenképpen alkalmazkodni kell a már meglévő, kialakult iskolai szokásrendhez. Az elindított, kompetencialapú megközelitésre támaszkodó folyamat további következményekkel jár, hiszen a pedagógusok fejlödése a tanulókkal folytatott munka eredményességében mérhető. Így a tanítás minőségének javítása a tanulás minőségének javulását is eredményezheti. Fontos volt számunkra az önkéntes jelentkezés érvényesülése, az, hogy a képzés helyben történjen, lehetőséget biztosítva ezáltal a képzők számára a helyi környezethez való optimálisabb alkalmazkodásra. Az adott pedagógusközösség egyéni igényeihez való igazodás, a rugalmasság által sikerült a képző intézmény és a részt vevő iskolák közötti partneri kapcsolat kialakítása, fenntartása (Falus, 2010; Szegedi, 2010).

\footnotetext{
${ }^{1}$ Az alprojekt résztvevői: Raoul Wallenberg Humán Szakképző Iskola és Gimnázium tanárai, a Pesti Barnabás Élelmiszeripari Szakképző Iskola és Gimnázium tanárai, az ELTE Bárczi Gusztáv Gyógypedagógiai Kar oktatói, valamint külső oktatók a gyakorló terepröl.
} 


\section{Sajátos nevelési igényü tanulók a középiskolákban}

Magyarországon a KSH adataira tudunk támaszkodni a tekintetben, hogy mennyi fogyatékos személy él társadalmunkban. Az adatok tájékoztató jellegúek, mivel az 1990-es és a 2001-es népszámláláskor „,bevallott tényekre” támaszkodnak. Az utolsó (2001) feldolgozott népszámlálás szerint 577 ezer fó, a népesség 5,7 százaléka volt fogyatékos személy. A tényleges szám legalább 600 ezer körül lehet. Közülük 32 százalék nem fejezte be az általános iskolát. Szakképesítéssel, illetve érettségivel 25 százalékuk rendelkezik, felsőfokú végzettsége 5 százaléknak van. A munkaerőpiacon betöltött szerepük, elfoglalt helyük ebből kifolyólag igen alacsony szintü és csekély számú (Köpatakiné, Mayer és Singer, 2007).

Az iskolák szerepe vitathatatlan a fenti arányok létrejöttében, ugyanakkor az iskolák lehetőséget is nyújthatnak ahhoz, hogy változzon ez a helyzet. Változzon az iskola is! Az óvoda és az általános iskola világában az együttnevelésben sikeres intézmények hatalmas átalakuláson mentek át. Innovatív tevékenységük a többségi gyermekek/tanulók számára is pozitív eredményeket hoztak (Kókayné és Montay, 1999). Középfokon, a fent jelzett nyitottság ellenére, sokszor csak fizikai jelenlétet és problémát jelent a sajátos nevelési igényü vagy beilleszkedési, tanulási, magatartási nehézséget mutató tanuló. A már korábban említett vizsgálat (Köpatakiné, Mayer és Singer, 2007) adatai összehasonlítási lehetöséget kínálnak a közoktatás teljes vertikumában a sajátos nevelési igényü tanulók arányáról (1. ábra).

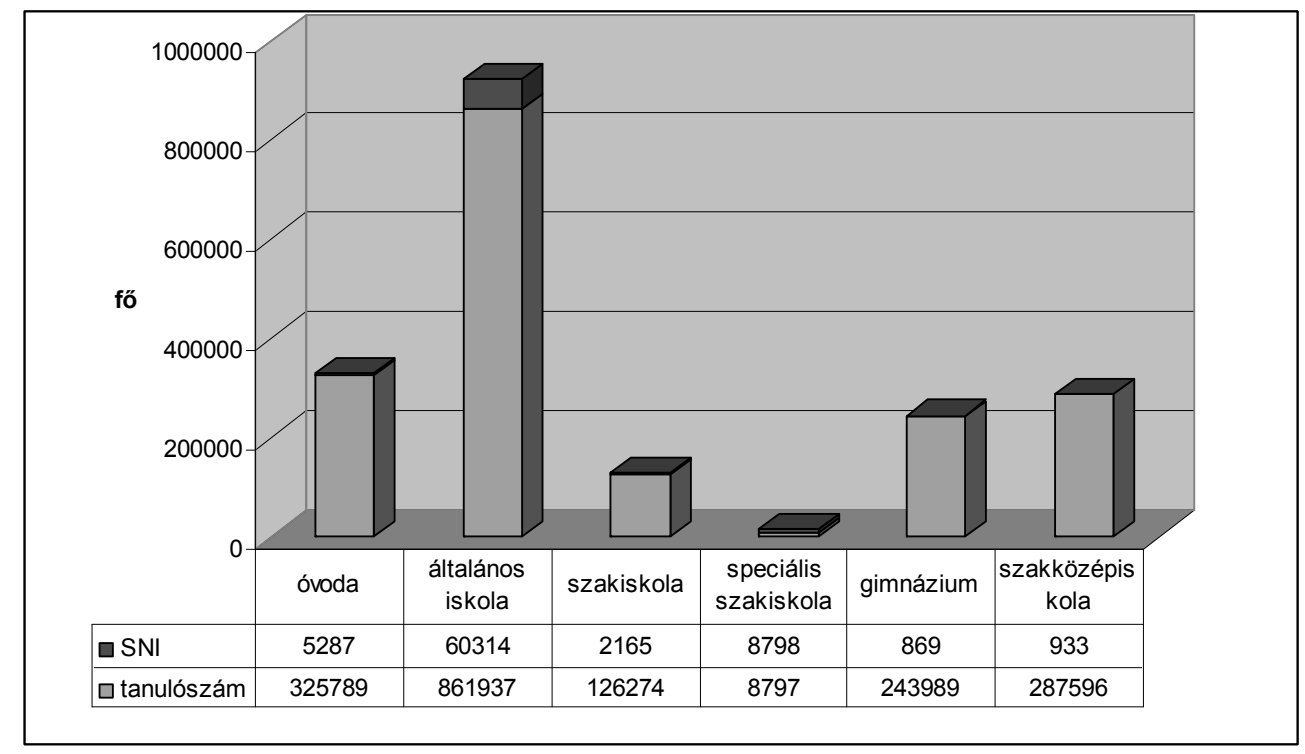

1. ábra: A sajátos nevelési igényü tanulók aránya az össztanulói létszámon belül 
Az adatokból kitünik, hogy míg a gimnáziumokban a sajátos nevelési igényű tanulók aránya 0,35 százalék addig a szakiskolákban ugyanez az arány 1,71 százalék, a speciális szakiskolákban pedig - értelemszerủen - 100 százalék.

Az együttnevelés folyamata hazánkban 1993 óta törvényi háttérrel is biztosított ${ }^{2}$, ́́gy mára az integrált nevelés-oktatás már a középiskolák szintjén is szélesebb körben elterjedt. Ennek hátterében az áll, hogy a tanulmányaikat a kezdetektől fogva integráltan folytató sajátos nevelési igényü gyermekek számára már kevésbé jelent akadályt a középiskolákba való bejutás, $\mathrm{s}$ ezt a jelenlegi demográfiai folyamatok (a csökkenő gyermeklétszám) is felerősítik.

Ezt a látszólag előremutató utat beárnyékolja az a tény, hogy a sajátos nevelési igényü tanulók megoszlása az egyes középfokú intézménytípusokban ellentétes tendenciát mutat a többségi tanulók megoszlásához képest. Kutatások bizonyítják, hogy a sajátos nevelési igényü tanulók legnagyobb arányban a speciális szakiskolákat, majd a szakiskolákat, a szakközépiskolákat és végül a gimnáziumokat választják; tovább rontja a helyzetet, hogy a sajátos nevelési igényü tanulók nagy száma lemorzsolódik a középiskolában (Köpatakiné, Mayer és Singer, 2007). Készültek olyan programok, amelyek segíteni hivatottak a középiskolákat a probléma kezelésében (Bognár, 2010; Schmitsek, 2011), illetve már létező jó gyakorlatokról is lehet hallani, olvasni (Vekerdy és Papp, 2006; Kapcsáné és Köpatakiné, 2007), ennek ellenére a középiskolákban továbbra is égető problémát jelent a sajátos nevelési igényü, tanulási, magatartási, beilleszkedési nehézséggel küzdő vagy hátrányos helyzetü tanulók támogatása.

Az integrált nevelés sikeres megvalósulásához szükséges komplex kapcsolati háló (tanuló, szülő, fogadó pedagógus, integrációt segítő gyógypedagógus) müködtetése még kevésbé jellemzi a középfokú intézményeket. A sajátos nevelési igényü gyermek számára - különösen, ha korábban nem járt speciális intézménybe - az integrált nevelés természetes élethelyzetet jelent, azonban a többségi intézmény fogadó pedagógusa az integrációt megelőzően más munkaformában, más munkastílusban dolgozott. Mint Petra Flieger (1979/1997, 219.) rámutat: „Manapság az integratív pedagógia irányában érdeklődést mutató pedagógusok jelentős hányadának nem állt módjában megismerni az integrált oktatás elemeit, s ugyanígy nem volt alkalma arra sem, hogy egy nem szelektáló iskolarendszerben dolgozhasson. Belső elképzeléseiket és beállítódásaikat arról, hogy voltaképpen mi is az iskola, az oktatás vagy a tanulás, s hogy mindezek hogyan müködnek, mindenekelött azok a saját maguk által szerzett tapasztalatok határozzák meg, melyeket - másra lehetőségük nem lévén - a szegregált, szelekciós mechanizmusoktól terhelt iskolarendszerben szereztek." (idézi Perlusz, 2004, 388. o.)

A középiskolai tanárok többnyire felkészületlenül állnak a probléma elött, nem rendelkeznek a feladat ellátásához szükséges kompetenciákkal. A módszertani kultúra

\footnotetext{
${ }^{2}$ Az 1993. évi LXXIX. törvény a közoktatásról
} 
bővítése, a szemléletváltás bekövetkezése azonban egy hosszú folyamat eredménye lehet (Vargáné, 2008). Az iskolák nem kérnek külső segítséget. Sokszor azt sem tudják, hol lehetne segítséget találni (Köpatakiné, Mayer és Singer, 2007). Nem ismerik a törvényben lefektetett jogokat és kötelességeket, a gyógypedagógiai ellátórendszert.

Az együtt tanulás, az integráció esély a tanulónak arra, hogy tanulmányai során birtokába kerüljön az a tudás, amivel az iskola elhagyása után hatékony munkaerőként, sikeres felnőttként éljen. Esély vagy csapda az integráció? Érvényesül-e a különleges gondozáshoz való jog? Az alapfokú oktatás többségében már müködő jogszabályok, pedagógiai intézkedések köre miért nem érvényesül középfokon is? Miért nem folytatódik számos jó gyakorlat az általános iskola után? Kidolgozott programunkkal ennek orvoslására próbáltunk kísérletet tenni, bízva abban, hogy a középiskolákban dolgozó pedagógusok nyitottak az új dolgokra, készek a tanulók hatékony ellátásra, várják a speciális tudást, aminek birtokában mindez megvalósulhat.

\section{A program előkészítése: igényfelmérés a pedagógusok körében}

A projekt során több középiskolát is megkerestünk, végül két olyan intézmény került kiválasztásra, melyekben hálózatos rendszerben, bázisiskolaként müködve több kollégát is érintett az együttnevelés kérdésköre. Bár a jelentkezés önkéntes volt, de a vezetőség mindkét esetben erősen szorgalmazta azt. A közismereti tárgyakat oktató tanárok mellett szakoktatók, müvésztanárok ( 2 fö) és a gyermekvédelmi felelös (1 fö) is részt vett a munkában.

A továbbképzés előtt igényfelmérö kérdőívet kaptak a résztvevők, melynek célja az volt, hogy a három alkalomból (23 óra) álló képzési programot az elözetes elvárásoknak, a pedagógusok igényeinek legmegfelelőbben állítsuk össze. A célcsoport az intézményben dolgozó pedagógusok, valamint a vezetők voltak, így részben hasonló, de részben különböző kérdéseket is kaptak, hiszen a vezetők pozíciójuknál fogva egy-egy kérdéssel kapcsolatban pontosabb információkkal, adatokkal (pontos tanulói létszámokra vonatkozó adatok) is rendelkeztek. A kérdőívben a pedagógusoknak lehetőséget adtunk a saját vélemény megjelenítésére is.

A kitöltési arány közel hasonló volt a két intézményben (27\%,37\%), bár nem mértük, de tapintható volt némi ellenállás is a képzéssel szemben. További ellenérzést keltett a túlterhelt pedagógusokban a késő délutánig tartó elfoglaltság, az idő elrablása más, kötelező tevékenységektől. A továbbképzés tervezésekor ezek az ellenérzések fontos információként jelentek meg számunkra. Mind módszertanát, mind tartalmát tekintve igyekeztünk a képzéssel rácáfolni ezekre az igényfelmérö kérdőívben megfogalmazott, valamint a korábbi továbbképzéseken szerzett tapasztalatokból származó félelmekre.

Az előzetes igényfelmérés legfontosabb eredményei a következők voltak. A pedagógusok nem minden esetben vannak tisztában azzal, hogy valójában ki a sajátos nevelési igényü tanuló. Nem mindig ismerik a tanulókról szóló szakértői véleményt. 
A sajátos nevelési igényü tanulók létszámára vonatkozóan a pedagógusok által megadott adatok jelentős mértékben eltérnek a vezetés által megadottól (ez utóbbi tekinthető a hivatalos adatnak), többnyire jelentősen túlbecsülik a sajátos nevelési igényü gyermekek számát, elsősorban a tanulási zavar területén. Ez fontos jelzés arra vonatkozóan, hogy a pedagógusok több gyermeknél érzékelnek problémát, mint ahány tanuló esetében ez szakértői véleménnyel valóban alátámasztott. Ennek hátterében az állhat, hogy mindkét intézményben viszonylag magas a beilleszkedési, tanulási és magatartási nehézséget (BTM) mutató tanulók száma, és e tanulók jelentős részét a pedagógusok a sajátos nevelési igényü kategóriákba tartozónak gondolják.

A sajátos nevelési igényü tanulók ellátását felzárkóztatással, a tanórán kívüli megsegítéssel oldják meg a leggyakrabban, ugyanakkor továbbra is sokan élnek az értékelés alól történő mentesítés biztosításával. Még mindig nagyon általános az a gyakorlat, hogy egyszerübb mentesíteni a tanulót az értékelés alól, mint megkeresni a segítségadás más formáját. Ugyanakkor ez a forma nem sarkallja nagyobb erőfeszítésre a sajátos nevelési igényü tanulót, $\mathrm{s}$ ráadásul feszültséget kelthet közte és az osztálytársai között. Az előzőeken túl a személyre szabott értékelést, a szóbeli vizsgát/feleltetést, a tágabb időkeret biztosítását, valamint a tanórai differenciálás (tanulópár, csoportmunka alkalmazása, személyre szabott órai feladat, feliratozás biztosítása stb.) lehetőségeit jelölték meg a pedagógusok a segítségnyújtás általuk alkalmazott formáiként.

Az órai tevékenységbe való külső segítő bevonása nagyon ritka a középiskolákban. Az igényfelmérés során nyert adatok is alátámasztották, hogy többnyire nem is tudnak erről a lehetőségröl.

A segítő szakemberek jelenlétére is kíváncsiak voltunk az intézményekben. Egyrészt arra, hogy ténylegesen milyen típusú, végzettségü segítő szakembereket alkalmaznak, másrészt arra, hogy erről tudnak-e a velük dolgozó középiskolai tanárok, szakoktatók. A pedagógusok általában nem voltak tisztában azzal, hogy milyen végzettségü szakemberek dolgoznak az iskolájukban. Több olyan segitő szakembert is megemlítettek, akik nem dolgoznak az intézményben, például pszichopedagógust, logopédust, fejlesztőpedagógust, szociális munkást, szociálpedagógust, illetve keverték az egyes kompetenciákat, így a pszichológusét a pszichopedagóguséval stb. Az igényfelmérés rávilágított arra, hogy segíteni kell a befogadó középiskolai tanárokat a segítő szakemberek kompetenciáinak és a velük való együttmüködés lehetőségeinek a megismerésében. Ez lehet az alapja annak, hogy ök is hatékonyan tudjanak segítséget nyújtani tanulóiknak.

A felmérésünk alapján világossá vált, hogy a sajátos nevelési igényü tanulók fogadására való felkészülés többnyire hiányzik a két középiskola gyakorlatából. A válaszoló kollégák a felkészülési lehetőségek közül a továbbképzések biztosítását nevezték meg, és hangsúlyozták a szakvélemények hozzáférhetőségének fontosságát. A pedagógusok jelezték, hogy az osztályfőnöknek van elsősorban lehetösége a tanulók megismerésére, azonban nem minden esetben adja át a megszerzett 
információkat kollégáinak. Valójában az információ megosztásnak lenne itt kiemelt szerepe, ugyanakkor ennek kevéssé van hagyománya a magyar közoktatás gyakorlatában (Köpatakiné, Mayer és Singer, 2007). Osztályszinten néhány pedagógus beszélget ugyan a diákjaival előzetesen a másságról és a fogyatékosságról, mely mindenképpen üdvözítő, de általánosan alkalmazott, hatékony érzékenyítésről nem beszélhetünk. A pedagógusok pozitívumként említették a konzultáció lehetőségét a gyermekvédelmi felelössel.

A továbbképzéseket áttekintve a két iskolában azt tapasztaltuk, hogy a kollégák sokirányúan képzettek, ugyanakkor jellemzően nem az egész tantestületet célzó képzésekről van szó, hanem az egyes pedagógusok egyéni érdeklődéséből fakadó részvételről. További nehézséget jelent, hogy a továbbképzéseken tanultakat kevesen építik be a napi gyakorlatukba és az egymástól tanulás lehetőségét sem használják ki kellő mértékben. Többen is megfogalmazták, hogy nincs alkalmuk a tanultak alkalmazására, amivel kapcsolatban időhiányra, a „lehetőség hiányára”, a „túl magas tanulói létszámra”, a „kevés szaktárgyi óraszámra”, az „iskolai túl- és leterheltségre" hivatkoztak. Ezeknek a hátterét a későbbiekben érdemes lenne tovább kutatni.

A „Miben vár segítséget az együttneveléshez?” kérdést a tréninghez kapcsolódóan fogalmaztuk meg, a válaszadók azonban olyan elvárásokat is megfogalmaztak, amelyeket a tréning alatt nem állt módunkban teljesíteni úgy, mint a segító szakemberek biztosítása az intézményben vagy éppen a munkakörülmények javítása stb. Jellemző volt, hogy a tantestület és a vezetés igénye csak részben egyezett meg. A válaszok alapján az derült ki, hogy a pedagógusok inkább kívülröl várják a segítséget, és kevésbé szeretnének maguk is tevékenyen részt venni a problémák megoldásában a vezetőkhöz viszonyítva.

A válaszoló pedagógusok nem érzik elégségesnek a tanulókkal kapcsolatos tudásukat, érzékenységüket és a velük való kommunikáció hatékonyságát. A pedagógusok megfogalmazták, hogy sokszor nem ismerik a tanulókról szóló szakvéleményeket, s valószínüleg az értelmezéshez is szükségük lenne segítségre. A tanulók megsegítésében a hangsúlyt a felzárkóztatásra helyezik, a tanulók fejlődéséhez, támogatásához, fejlesztéséhez kézzelfogható segítséget várnak. A tanórai és azon kívüli tanulás szervezéséhez nem tartják elégségesnek a tudásukat, a sajátos nevelési igényü tanulókkal kapcsolatos feladatok ellátására nem érzik kompetensnek magukat.

Az intézmények vezetői az igényfelmérő kérdőívben erős igényüket fejezték ki a team-tanításra és a gyógypedagógus jelenlétére a tanórákon. Véleményük szerint a tanárok kevésbé alkalmazzák a tanórai differenciálást és ehhez kapcsolódóan a kooperatív tanulás különböző formáit. Nem vagy csak ritkán használják ki a team munka lehetőségeit az azonos tanulóval foglalkozó kollégák. A vezetők fontosnak tartották a Közoktatásról szóló törvény (1993. évi LXXIX. törvény a közoktatásról) értelmezését, valamint az intézményi dokumentumok átnézéséhez, átdolgozásához, a jog- 
szabályoknak való megfeleltetéshez a segítségnyújtást. Az igényt a tréningre vonatkozóan fogalmazták meg, valamint felhívták a figyelmet arra, hogy az Egységes Gyógypedagógiai Módszertani Intézmények szolgáltatásainak ez irányú bővítése is szükséges a jövőben.

\section{A tréning alapú továbbképzés célja és tematikája}

Az igényfelmérő kérdőívek összesítése, valamint az intézményekkel történő egyeztetést követően került sor a végleges programajánlat kialakítására, mely erőteljesen épített a pedagógusok önálló, csoportokban történő munkájára.

A képzés célját az alábbiakban határoztuk meg: „...a sajátos nevelési igényü tanulók középfokú integrált oktatásához-neveléséhez szükséges alapvető információk és tanítási stratégiák megismertetése. A képzés révén a középiskolai pedagógusok ismerjék meg az egyes sajátos nevelési igényủ csoportok jellemzőit, speciális szükségleteiket az oktatási-nevelési folyamat során. Képessé váljanak a tanulási folyamat tervezésére, szervezésére a tanulók sajátos szükségleteinek figyelembevételével. Ismerjék meg azokat a dokumentumokat, eljárásokat, segítő technikákat, melyekkel e tanulók sajátos igényei kielégíthetők." (Akkreditációs dokumentum).

A képzés során három alkalommal találkoztunk a résztvevőkkel. A következőkben ezeknek a tartalmát ismertetjük röviden.

\section{Első alkalom: Érzékenyités}

Érzékenyítés a tantestület egésze, valamint igény szerint a tagintézmények sajátos nevelési igényü tanulókkal foglalkozó pedagógusai számára. Pozitív attitủdváltást, elfogadást, empátiát és toleranciát célzó, az egyéni különbségek folyamatos figyelemmel kísérésére ösztönző saját élményü tapasztalatszerzés nyújtása szimulációs gyakorlatokon keresztül.

Második alkalom: A tantestület tájékoztatása, elméleti ismeretek nyújtása

Heterogén csoportokban adott témakörök feldolgozása, csoportok alakítása mozaikmódszerrel, majd a csoportfeladatok kiosztása és megbeszélése. Információk átadása a következő témakörökben:

- Az integráció-inklúzió témakörével kapcsolatos fogalmak tisztázása, értelmezése; törvényi háttér.

- Diagnózis, szakértői vélemény értelmezése, elemzése.

- Fejlesztő munkát segítő eszközök, szakanyagok bemutatása, megfelelő eszköztár kialakítása az intézményben.

- Pedagógiai tanácsadás, módszertani és tanulásszervezési segítségnyújtás.

- A sajátos nevelési igényü gyermekekre vonatkozó pszichológiai tanácsadás.

- Team-tanítás. 
A továbbképzés második alkalma a kiosztott csoportfeladattal zárult, ezt a résztvevőknek a harmadik alkalomra kellett kidolgozniuk öt-hét fös csoportokban. A csoportalkotás kritériuma: a pedagógusok mindegyike ismerje és tanítsa az adott tanulót. A részt vevők az alábbi algoritmussort kapták meg a harmadik alkalomra elkészítendő csoportfeladat elvégzéséhez:

1. Válasszanak ki egy SNI tanulót, vagy olyan tanulót, akinek a többség egyetértése szerint tanulási nehézségei vannak!

2. Fogalmazzák meg azt a problémát, amelyet a tanulóval kapcsolatban meg kívánnak oldani!

3. Tekintsék át a tanuló iratanyagát (például szakértői vélemény, nevelési tanácsadó véleménye, tantárgyi tesztek eredményei, orvosi papírok, pedagógus megfigyelései stb.)

4. Tekintsék át a rendelkezésre álló személyi és tárgyi feltételeket a törvényi lehetőségek alapján!

5. Tekintsék át, hogy a felmerült probléma megoldására rendelkezésre állnak-e a fejlesztó munkát segítő eszközök, szakanyagok. Milyen módon bővíthetőek ezek a lehetőségek?

6. Fogalmazzák meg, hogy a felmerült probléma megoldására milyen módszertani és tanulásszervezési eljárásokat alkalmaztak eddig, milyen eljárások kipróbálására látnak lehetőséget és ehhez milyen pedagógiai, pszichológiai, gyógypedagógiai tanácsadásra lenne szükségük, illetve kitől kaphatnák ezt meg?

7. Vázolják fel a problémamegoldás menetét, külön felsorolva a már meglévő, alkalmazott lehetőségeket, illetve azokat, melyek megteremtését, kipróbálását, fejlesztését az adott tanuló problémája kapcsán kezdenék meg!

8. Készítsen a csoport erről egy max. öt perces prezentációt, jelöljenek ki egy szóvivőt, aki ismerteti a feladatmegoldást!

Harmadik alkalom: Esetmegbeszélés

A beszámolás a korábban megadott szempontok alapján történt. A feladat sikeres megoldásához szükség volt a képzésen elsajátított tartalmak (attitüd, ismeretek, készségek, eljárások) alkalmazására. A prezentációnak tükröznie kellett a csoporttagok együttmüködését és közös feladatmegoldását is. A készitett prezentáció értékelésének szempontjai az alábbiak voltak:

- a probléma adekvát megfogalmazása,

- a probléma több szempontú megközelítése, figyelembe véve a tanulóval kapcsolatos előzetes tudást, vizsgálati anyagokat, alkalmazott eljárásokat,

- a problémára adott lehetséges válaszok relevanciája,

- a csoporttagok feladatmegosztása és együttmüködése.

A kiscsoportos beszámolókat a képzés oktatói és a tanfolyam résztvevői közösen hallgatták meg. Minden csoport kapott visszajelzést a munkájáról, melyet 
a tréning vezetői közösen fogalmaztak meg, kiemelve a pozitív, minta értékủ elemeket a bemutatókban. A korszerủ pedagógus továbbképzés jellemzőit szem elött tartva hangsúlyt kapott

- az iskola, a pedagógusok innovációs tevékenysége,

- a kollégák együttmüködése,

- az egyes csoporttagok tudásmegosztó tevékenysége,

- az intézmény tudásmegosztó tevékenysége,

- a kollégák tanulóközösséggé válása,

- a probléma-kezelés új kultúrájának a kialakítása,

- az egymáshoz és a tanulóhoz való alkalmazkodás megjelenése.

Így váltak a képzők és a tanulók (tréningvezetők és középiskolai kollégák) egymással együttmüködő csapattá.

\section{A program eredményei}

A középiskolai kollégák tényleges esetek köré szervezték munkájukat. Felhasználták a tréningen tanultakat, kooperatív mozaikcsoportban gyüjtötték össze a lehetséges megoldásokat. Korábban nem használt problémakezelési módszereket írtak le, sőt volt olyan csoport, amelyiknek egyik tagja ki is próbálta a csoport által javasoltakat, az egyébként rövid idő alatt. A csoportmunkák és az azok alapján készült prezentációk - véleményünk szerint - igazolták, hogy átgondolt és megfelelően tervezett feladatválasztással növelhető a résztvevők érdeklődése, aktivitása, elkötelezettsége. Megvalósult a tudásmegosztás, a kollégák közötti együttmüködés és képesek voltak az általuk megfogalmazott problémákra adekvát válaszokat adni.

\section{A programmal való elégedettség}

A program végén a részt vevő pedagógusoktól ( 83 fö) név nélkül elégedettségi kérdőiv kitöltését kértük. A kitöltési aktivitás a két intézményben összesen (57 fö) 69 százalékos volt.

A képzéssel való globális elégedettséget egy 10 fokú skálán 6,8-ra, míg a képzés hatékonyságát 6,7-re értékelték a pedagógusok. A válaszolók nagy része (84\%) a képzés végén úgy ítélte meg, hogy jobban ismeri az egyes fogyatékossági kategóriákat és ezek jellemzőit, mint a tréning előtt. Nyolcan nemmel válaszoltak e kérdésre, amiből arra is következtethetünk, hogy esetükben nem volt eredményes a képzés, de arra is, hogy ők már korábban is rendelkeztek ismeretekkel az egyes fogyatékossági kategóriákról és jellemzőikről. Akik megfelelőnek érezték az egyes fogyatékossági kategóriákról, csoportokról kapott ismereteket, a következöképpen nyilatkoztak: „mélyült a meglévő tudásom”, „sok információt kaptam”, „felkészültek voltak az előadók”, ,jobb rálátásom lett”, „új segédeszközöket ismertem meg”. 
Azok a pedagógusok, akik nem tartották megfelelőnek az egyes fogyatékossági csoportokról kapott ismereteket, az alábbi véleményüket fogalmazták meg: „kevés volt az idő”, „néha túl szakmai volt a program”.

Voltak olyan válaszok is, amelyek azt jelezték, hogy középfokon még mindig jellemző az idegenkedés, távolságtartás a sajátos nevelési igényü tanulók integrációjától: „,nem tartom létezőnek a fogyatékos kategóriákat (kivéve testi fogy.)”; „a szakképzésben alig van SNI-s tanuló”.

Programunkkal azt szerettük volna elérni, hogy a középfokú oktatás-nevelési intézmények sajátos nevelési igényű tanulókkal szembeni attitüdjei kedvezőbbekké váljanak, növekedjen a fogadókészség, illetve a speciális szükségletek kezelésével kapcsolatos konkrét ismeretek, technikák átadásával az integrált oktatás-nevelés eredményessége is hatékonyabbá váljon. Az alábbiakban látható, hogy a program elérte ez irányú törekvéseit.

A képzési program tervezése során egyik részcélunk az volt, hogy segítséget nyújtsunk a középiskolai pedagógusoknak a sajátos nevelési igényü tanulók szakvéleményeinek értelmezéséhez. Ezt a kérést maguk a pedagógusok is megfogalmazták az igényfeltárás során. A képzés végén a válaszadó pedagógus 74 százaléka (42 fö) gondolta úgy, hogy kapott segítséget a szakvélemény értelmezéséhez.

A pedagógusok túlnyomó többségének sikerült a tréning során olyan módszertani eljárásokra, stratégiákra, ötletekre is szert tennie, melyek valószinüsithetöen megkönnyitik majd osztálytermi munkájukat a sajátos nevelési igényü tanulókkal. Így állíthatjuk, hogy programunk másik célkitüzése, ,,a speciális szükségletek kezelésével kapcsolatos konkrét ismeretek, technikák átadása", a válaszolók többségénél eredményes volt. Természetesen voltak, akik nem voltak elégedettek a programmal ebből a szempontból, ők az „ennyi idő alatt erre nincs lehetőség”, illetve a „kevés gyakorlati elem” megjelenésére hivatkoztak.

A kollégák 72 százalékának (41 fö) újdonságot jelentett a segitő szakemberekkel történö együttmüködésnek egy vagy több formája, amelyeket a képzés során bemutattunk (utazótanári megsegítés, team-tanítás, kéttanáros modell, konzultáció). Ez arra is utal, hogy a középfokú integráció során kevéssé valósul meg a többségi pedagógus és a gyógypedagógus együttmüködése, valamint arra is, hogy ennek a legmodernebb megoldásmódjai (például az osztálytermen belüli megsegítés) pedig egyáltalán nem léteznek a hazai gyakorlatban. A résztvevők 26 százaléka (15 fö) számára a bemutatott formák nem hoztak újat. Az utóbbi válasznak akár örülhetnénk is, ha mindez azt jelentené, hogy az ismertetett megoldási módok elterjedtek a középfokú oktatás során.

A segítő szakemberekkel való együttmüködés elutasítását tartalmazó válaszok minőségi elemzése rámutatott arra is, hogy a résztvevő pedagógusok egy része hogyan vélekedik az ismertetett korszerű segítségnyújtási formákról. Többen kiemelték a segítő szakemberek hiányát, vagyis azt, hogy jó lenne fejlesztő pedagógus, illetve utazó gyógypedagógus az iskolában. Ök a team tanítást azért sem tartották 
reális lehetőségnek, mert a jelenlegi helyzetben, a napi gyakorlatban nem találkoznak segítő szakemberrel. Olyan vélemények is megfogalmazódtak, hogy „A team tanítás híve vagyok, de sokan elutasítják, mert nem akarnak alkalmazkodni.”, vagy „Nehézséget jelentene a munkában.”. Mindez arra (is) utal, hogy a hazai pedagógiai kultúrában nem terjedt el a különböző kompetenciájú szakemberek együttmüködése, a tanulókért vállalt felelösség megosztása. Sokkal inkább „az én váram”, vagy a pedagógus „magányos harcos” szemlélet uralkodik, másképpen fogalmazva, a pedagógusok senkit sem látnak szívesen magukon és a tanulókon kívül az osztályteremben.

A válaszadók 65 százaléka (37fö) gondolta úgy, hogy a tréning során megismert olyan új, tanulást segitö eszközöket, eljárásokat, melyeket hatékonyan tud majd alkalmazni a sajátos nevelési igényü tanulók oktatásában, nevelésében. A többségben lévő igen válaszok számunkra azért is örvendetesek, mert a tréning során a résztvevők olyan tanulást segítő eszközöket is megismerhettek és kipróbálhattak, melyekről nem volt tapasztalatuk, esetleg még az általuk oktatott sajátos nevelési igényü tanuló sem használta azokat, így új tudásuk alapján ők is tudnak majd a tanuló számára javaslatot tenni bizonyos eszközök használatára. Hasonlóan igaz ez a tanítási-tanulási technikákra is.

Korábbi gyakorlati tapasztalataink alapján - miszerint a többségi pedagógusok, intézményvezetők kevéssé ismerik azokat a jogszabályokat, melyek az integrált oktatásra, nevelésre vonatkoznak - a képzési program részét képezte az integrált nevelés - oktatás jogi hátterének rövid ismertetése, az integrált tanulók számára igénybe vehető könnyítések bemutatása is. Ezzel a témával kapcsolatban a résztvevők 80 százaléka (45fö) vélekedett úgy, hogy a képzés segítette a jogszabályokban való eligazodást, amit azért is fontos eredménynek vélünk, mert az integrált nevelés gyakorlati megvalósulásának hiányosságai, a feltételek biztosításának elmaradása sokszor éppen a jogszabályok elégtelen ismeretéből ered. A válaszadók megfogalmazták, hogy „megismerhették a lehetőségeket”, „elősegítette a tisztánlátásukat”, „rendezettebb lett a tudásuk ezen a területen”, illetve segítséget kaptak, hogy „milyen szakemberhez forduljanak”, „hogyan készítsék el az iskolai értékelés alól történő mentesítéseket". Ugyanakkor olyan válasz is megfogalmazódott egy válaszadó részéről, hogy „nem értem, hogy miért erőltetik az integrált oktatást”, illetve „eddig is megoldódtak a problémák".

Képzésünkkel nem titkolt célunk volt az is, hogy segítsük a középiskolai pedagógusokat a sajátos nevelési igényü tanulók számára nyújtandó egyéni bánásmód szükségességének megértésében és technikáinak elsajátíttatásában. Ez a differenciált bánásmód nélkülözhetetlen a sajátos nevelési igényü tanulók eredményes haladása szempontjából, ugyanakkor általános tekintetben is növeli az oktatás hatékonyságát. Az a pedagógus, aki képes az integrált tanuló egyéni szükségleteire figyelemmel szervezni az oktatást, érzékenyebbé válik a többi tanuló különbözőségére is. A válaszolók 70 százaléka (40fö) érezte úgy, hogy a képzés növelte kompetenciá- 
jukat az egyéni bánásmód biztosítása területén. Akik ennek az ellenkezőjét jelezték vissza (14 fö), az ő esetükben szeretnénk azt hinni, hogy az nevelö-oktató munkájuk során tekintettel tudnak lenni a tanulók egyéni szükségleteire. A pozitívan válaszolók kiemelték, hogy könnyebbé vált számukra az egyéni szükségletek felismerése, sok új lehetőséget, módszert ismertek meg, megerősítést kaptak a munkájukhoz, tudatosabb lett a hozzáállásuk. Két válaszadó a konkrét tantárgyi, módszertani megsegítés elmaradását fogalmazta meg.

A résztvevőktől ,a tréning előadóival kapcsolatos globális elégedettség értékelését" is kértük. A tíz fokú skálán kapott 7,85-8-as eredmény számunkra fontos visszajelzés, mely arra utal, hogy az általunk vállalt feladatot a többség számára hitelesen tudtuk közvetíteni.

A program továbbfejlesztésével kapcsolatban javaslatokat is kértünk a résztvevő kollégáktól. Ennek kapcsán megfogalmazódott, hogy a délutáni kezdés sok esetben igencsak igénybe veszi az amúgy is túlterhelt pedagógusokat, hogy az első alkalom tíz-tíz perces, fogyatékossági csoportokat bemutató előadásait is interaktívabbá kellene tenni, illetve még több gyakorlatot igényelnének a pedagógusok. Ugyanakkor pozitívumként emelték ki a kollégák a „,forgószínpadszerü” prezentációs részt, illetve a harmadik alkalomra csoportmunkában elkészítendő feladatot. Javaslataikat a következő képzéseinkbe igyekszünk beépíteni.

\section{Összegzés}

Köszönettel tartozunk a részt vevő intézményeknek, a vezetőknek és a pedagógus közösségnek, hogy nyitottak voltak a programunkra és elfogadták az általunk nyújtott lehetőséget. Sokat tanultunk mi is tőlük. A képzés során a legfontosabb tapasztalat az volt, hogy a felnőttek, különösen a pedagógusok képzése során igen körültekintően kell eljárni a módszerválasztás tekintetében. Jó módszerekkel megnyerhetjük a résztvevőket az ügynek, de ennek hiányában el is veszíthetjük őket. Programunkat összességében sikeresnek értékeljük, hiszen a felmért igényekre közel 80 százalékban meg tudtunk felelni. Reméljük, hogy programunkkal a részt vevő intézményekben hozzá tudtunk járulni a sajátos nevelési igényü tanulók integrációjának sikerességéhez. Végezetül álljanak itt egy résztvevő dicsérő szavai: „Kiváló, humánus, gyermekszerető pedagógusgárda jött el hozzánk. Nyitottak voltak minden kérdésünkre, problémánkra. Lenyügözött a felkészültségük, intelligenciájuk és az ügy iránti odaadásuk."

A kidolgozott tréningalapú képzés akkreditációja (30 órás pedagógus továbbképzésként) megtörtént az ELTE Bárczi Gusztáv Gyógypedagógiai Karon. 


\section{Irodalom}

Bognár Mária (2010): A Fogyatékos Személyek Esélyegyenlőségéért Közalapítvány szakmai vezetésével megvalósuló Dobbantó projekt. Új Pedagógiai Szemle, 10-12. sz. 102-116.

Falus Iván (2010): A pedagógusképzés korszerűsítése - európai tendenciák. Pedagógusképzés, 1. sz. 19-36.

Flieger, P. (1979/1997): A tanárok integrált oktatással kapcsolatos beállítódásainak változása. Metodikai megfontolások a pedagógus továbbképzésekhez. In: Zászkaliczky Péter (szerk.): A gyógypedagógia új útjai. Vydavatel'stvo Liecreh Gúth, Bratislava, 1997, 217-226.

Kőpatakiné Mészáros Mária, Mayer József, Singer Péter (szerk., 2007): Akadálypályán. Sajátos nevelési igényü tanulók a középfokú iskolákban. SuliNova Educatio Társadalmi Szolgáltató Kht., Budapest.

Kapcsáné Németi Júlia, Kőpatakiné Mészáros Mária (szerk., 2007): Sajátos nevelési igényü tanulók a szakiskolában - avagy az együtt nevelö szakiskola mint a társadalmi integráció előszobája. Nemzeti Szakképzési és Felnőttképzési Intézet, Budapest.

Kókayné Lányi Marietta, Montay Beáta (1999): Sokfélék az elindulók és nem egyformák az utak. In: Füzfa Balázs (fel. szerk.): Süss fel nap. Kisgyermekkori modell-intézmények Magyarországon. Soros Alapítvány, Budapest, 178-197.

Papp Gabriella (szerk., 2011): Középiskolás fokon?! Sajátos nevelési igényü fiatalok együttnevelése a középiskolákban. ELTE Eötvös Kiadó, ELTE Bárczi Gusztáv Gyógypedagógiai Kar, Budapest.

Perlusz Andrea (2004): A hallássérült gyermekek nyelvi fejlesztése a hallók iskolájában. In: Gordosné Szabó Anna (szerk.): Gyógyító pedagógia. Medicína Könyvkiadó RT, Budapest, 385-397.

Schmitsek Szilvia (2011): „Dobbantó”-val a szakképzésbe (a személyre szabott pedagógiai gyakorlat megvalósulása a szakképzésben, a lemorzsolódás visszaszorítása érdekében) In: Klein Sándor - Soponyai Dóra (szerk.): A tanulás szabadsága Magyarországon. Alternatív pedagógiai irányzatok, iskolák, tanárok, tantárgyak. Edge $2000 \mathrm{Kft}$., Budapest, 587-597.

Stéger Csilla (2010): A pályakezdő tanárok bevezető támogatási rendszerével kapcsolatos uniós törekvésekröl. Pedagógusképzés, 1. sz. 37-58.

Szegedi Eszter (2010): Egész életen át tartó tanulás, szakmai fejlődés a tanári pályán. A Tempus Közalapítvány közremüködése az európai gondolatok terjesztésében. Pedagógusképzés, 1. sz. 7-18.

Vargáné Mező Lilla (2008): A sikeres együttnevelés kulcselemei. In: Vargáné Mező Lilla (szerk.): Tovább az akadálypályán. Prevenciós lehetőségek a sajátos nevelési igényü tanulók középiskolai lemorzsolódásának és idő elötti iskolaelhagyásának megelözésére. Educatio Társadalmi Szolgáltató Kht., Budapest, 15-30.

Vekerdy Tamás, Papp Ágnes (szerk., 2006): Van más megoldás is - alternatív módszerek a középiskolában. Pedagógiai Alternatívák. 10. kötet; Sulinova Kht. Pedagógiai Alternatívák Központja, Budapest. 